\title{
PENGARUH MENDENGARKAN MUSIK TERHADAP MOOD BELAJAR PADA MAHASISWA MANAJEMEN DAKWAH UIN SUSKA RIAU
}

\author{
Lailatul Izzah \\ Program Studi Psikologi Islam, STAI Diniyah Pekanbaru \\ izzah@diniyah.ac.id \\ Rahmawati \\ Program Studi Manajemen Dakwah, UIN Suska Riau \\ Hilyatul Humairoh \\ Program Studi Manajemen Dakwah, UIN Suska Riau
}

\begin{abstract}
The purpose of this study was to study the picture of student learning atmosphere and to study the influence of musk in the learning atmosphere of the third semester students of Da'wah Management UIN Suska T.A. 2019/2020 Pekanbaru. The method used in this study is a field survey research using questionnaires, interviews and observations, data analysis techniques used in this study with descriptive techniques. The sample in this study denied 36 third semester students of Da'wah Suska Riau Management in the academic year 2019/2020 who had a mood in learning in the lace category. Data collection techniques in this study used a learning mood questionnaire, interviews, observation and documentation as supporting techniques. The results of this study found that $75 \%$ of students listen to music while studying work on college assignments and $25 \%$ of students listen to music when there is no lecture. $80 \%$ of students who listen to music have the same reason they listen to learning compilation music, which is so they don't get bored while studying, because their hobbies are listening to music and increasing their creativity in thinking, adding vocabulary. While $13.3 \%$ of students who listen to music have reason to listen to music while learning to make them calm. And a reasonable break listening to music while learning makes learning that can be learned easily, can eliminate nervousness and likes the singer. $80 \%$ of students who listen to music when learning to listen to a type of music that is glance (pop and k-pop).
\end{abstract}

\begin{abstract}
ABSTRAK
Tujuan penelitian ini untuk mengetahui gambaran mood belajar mahasiswa dan untuk mengetahui pengaruh musk dalam mood belajar mahasiswa semester III Manajemen Dakwah UIN Suska T.A. 2019/2020 Pekanbaru. Metode yang digunakan dalam penelitian ini adalah penelitian survey lapangan dengan menggunakan angket, wawancara dan observasi, teknik analisis data yang digunakan pada penelitian ini dengan teknik deskriptif. Sampel dalam penelitian ini berjumlah 36 mahasiswa semester III Manajemen Dakwah Uin Suska Riau tahun ajaran 2019/2020 yang memiliki mood dalam belajar dalam kategori renda. Teknik pengumpulan data dalam penelitian ini menggunakan angket mood belajar, wawancara, observasi dan dokumentasi sebagai teknik pendukung. Hasil penelitian ini didapat $75 \%$ mahasiswa mendengarkan musik dalam belajar atau saat pengerjaan tugas kuliah dan $25 \%$ mahasiswa mendengarkan musik pada saat waktu kosong perkuliahan. 80\% mahasiswa yang mendengarkan musik mempunyai alasan yang sama mengapa mereka mendengarkan musik ketika belajar, yaitu agar tidak bosan saat belajar, karena hobi mendengarkan musik dan meningkatkan kreativitas berfikir, menambah kosa kata. Sedangkan 13,3\% mahasiswa yang mendengarkan musik beralasan mendengarkan musik saat belajar membuat mereka tenang. Dan sisanya beralasan mendengarkan musik saat belajar membuat pembelajaran yang sedang dipelajari mudah diingat, dapat
\end{abstract}


menghilangkan rasa gugup dan suka penyanyinya. $80 \%$ mahasiswa yang mendengarkan musik saat belajar mendengarkan jenis musik yang berlirik (pop dan k-pop).

Kata Kunci : Musik, Mood, Mahasiswa

\section{PENDAHULUAN}

Musik bagi manusia sudah menjadi kebutuhan, dengan musik kita bisa mengkondisikan diri kita pada tingkat ketenangan jiwa dimana musik bisa menghibur dan menentramkan hati karna mampu merangsang rasa bahagia yang dikirim oleh otak lalu diiringi oleh detak jantung yang menyesuaikan irama lagu yang didengar, sehingga menimbulkan perasaan nyaman. Musik didengarkan untuk mengiringi suatu gerakan atau kegiatan. Musik bisa mempengaruhi perasaan, dan perasaan mempengaruhi pembelajaan. Jenis musik yang tepat cenderung mengendalikan sekaligus menggugah otak dan seluruh sistem syaraf. Jadi musik yang dimanfaatkan secara tepat dapat mengaktifkan kemampuan total mereka lebih banyak karena mereka mengerahkan pikiran sepenuhnya untuk belajar (Djon, 2016)

Musik merupakan seni bunyi yang diatur menjadi pola yang dapat menyenangkan telinga kita atau mengkomunikasikan perasaan atau suasana hati. Mereka yang beranggapan bahwa musik berfungsi sebagai sarana katarsis meyakini bahwa musik juga dapat menjadi sarana pengekspresian diri. Musik diakui mempunyak kekuatan untuk mengantar dan mengugah emosi, baik dituangkan melalui penjiwaan terhadap alur cerita, musik dan watak tokoh yang diperankan maupun sebagai saranan untu mengekspresikan diri. Oleh sebab itu, musik tidak dapat dipisahkan dari emosi. Penjiwaan karakter dalam opera, misalnya terkait dengan sederet ekspresi emosi. Sementara sebagai sarana ekspresi diri, emosi adalah parameter yang tidak terhindarkan (Djon, 2016).
Musik sangat familiar dalam kehidupan, berbagai belahan dunia mengindikasikan bahwa manusia telah menikmati musik sejak zaman batu. Hingga saat ini musik telah menjadi 'sahabat' ketika orang melakukan aktifitas kehidupan sehari-hari seperti sedang belajar, tidur, memasak, saat mereka sendiri, termasuk juga saat mengerjakan tugas atau mengerjakan pekerjaan rumah.

Adapun orang mendengarkan musik dalam kehidupannya dikarnakan musik dapat memberikan rasa yang baik (fellingbetter), jarang mendengarkan musik dapat menimbulkan rasa yang tidak positif. Merurut Saloboda \& Justin, "perasaan lebih baik ini muncul karna relasi musik dengan emosi, yaitu musik dapat membuat orang merasakan senang, sedih, serta dapat memberikan ketenangan bagi pendengarnya". Dengan demikian bahwa emosi pada diri manusia dapat ditimbulkan oleh musik, jadi emosi tersebut dapat membuat individu merasakan perasaan yang positif atau perasaan yang lebih baik. (Goleman, 2003) dalam bukunya "Kecerdasan Emosi Untuk Mencapai Prestasi" mengemukakan tentang kerangka kerja kecakapan emosi yang meliputi: (1) kecakapan pribadi yang terdiri dari kesadaran diri, pengaturan diri, dan motivasi; (2) kecakapan sosial yang terdiri dari empati dan ketrampilan sosial.

Kecakapan emosi ini menjadi penting untuk diungkap mengingat bahwa emosi manusia secara umum terbagi kepada dua yaitu emosi positif dan emosi negatif. Seseorang yang pandai atau memiliki kecakapan emosi diharapkan mampu untuk lebih mengembangkan emosi positifnya dibanding dengan emosi negatifnya (Goleman, 2000). Musik 
sendiri dianggap menimbulkan emosi positif bagi pendengarnya, karna itulah keluar anggapan bahwa mendengarkan musik dapat mempengaruhi mood atau emosi seseorang kepada hal-hal yang positif seperti belajar dan mengerjakan tugas. Mendengarkan musik ketika belajar merupakan salah satu usaha seseorang dalam meningkatkan kualitas belajarnya dan mengembangkan keterampilan dirinya melalui emosi positif yang dihasilkan dari mendengarkan musik. Fenomena yang terjadi pada saat ini saling berhubungan dengan teori-teori para ahli mengenai mendengarkan musik dapat mempengaruhi emosi seseorang.

Jika ingin melatih kekuatan fisik lakukan olahraga. Namun jika mengasah kekuatan otak, dengarkanlah musik. Mengapa demikian ? sebab manfaat mendengarkan musik untuk kesehatan maupun tubuh secara keseluruhan sangat besar. Musik, dinilai dapat meredakan stres membuat kita menjadi lebih semangat, dan bahkan dapat membantu meredakan nyeri. Para ilmuwan dari University of Missouri setuju bahwa mendengarkan musik dapat memperbaiki mood orang-orang yang mendengarkannya. Penelitian yang dipublikasikan dalam The Journal of Positive Psychology ini mengungkapkan bahwa perbaikan mood dan penurunan tingkat stres tampak terlihat setelah 2 minggu rutin mendengarkan musik.

Beradasarkan apa yang dipublikasikan para peneliti dari Mc-Gill University di Montreal, Amerika Serikat, mengatakan bahwa mendengarkan musik membuat mood kita terpengaruh karena musik membuat tubuh menghasilkan dopamin dalam kata lain cairan yang ada di dalam otak yang mengahsilkan rasa senang, sedih, marah, kecewa dan lain lain. Meningkatkan dopamin di dalam otak yang merespon musik membuktikan bahwa manusia mendapat kesenangan setelah mendengarkan musik. Sehingga musik memiliki peranan dalam menentukan, mengembangkan dan melanjutkan kecerdasan seseorang remaja.

Banyak cara kita untuk dapat mengakses musik dengan mudah pada era modern saat ini. Bisa mendengarkannya secara onlien ataupun offline, dan kita bisa mendownload musik yang kita sukai, serta kita butuhkan baik kapanpun dan dimanapun kita berada. Hal ini juga dapat terlihat dari hasil observasi dan survey pada tanggal 20 Oktober 2019 di kelas Manajemen Dakwah UIN Suska, terlihat banyaknya mahasiswa yang mendengarkan musik melalui gadgetnya ataupun lapotop dalam pada saat mengerjakan tugas dan belajar atau sebelum akan memulai belajar atau membaca buku. selain itu pada wktu luang seperti saat istirahat dan jam kosong untuk memainkan gadgetnya dan mendengarkan musik. Dari Observasi yang telah saya lakukan, mayoritas mahasiswa tersebut selalu melampiaskan apa yang mereka rasakan dengan mendengarkan musik. Baik itu senang, kesal, marah.

Bagi mahasiswa sendiri yang memiliki tugas yang lebih fleksibel dibandingkan siswa sekolah, mendengarkan musik mengerjakan tugas dna belajar dianggap mampu meningkatkan mood dalam belajar. Berdasarkan latar belakang dan fenomena di atas, penulis tertarik untuk melihat bagaimana Pengaruh mendengarkan musik terhadap mood dalam belajar pada Mahasiswa Manajemen Dakwah UIN Suska Riau.

Menurut mereka, mereka bisa leih tenang pada saat merasakan rasa jenuh. Bahkan ada beberapa mahasiswa yang mendengarkan musik sebelum waktu perkuliahan dimulai, dan ada yang memutar musik bersama pada saat perkuliahan berakhir, dengan alasan "lebih santai, tidak tegang dan enjoy", Ujar mereka.

Berdasarkan hasil pra-penelitian mendengarkan musik merupakan salah satu langkah untuk menghilangkan kejenuhan pada mahasiswa dan adanya keterkaitan bahwa musik dapat 
mempengaruhi mood belajar seseorang, baik itu kejenuhan, sedih, kesal, marah, bahagia dan sebagainya.

Oleh karena itu, peneliti tertarik untuk meneliti tentang Pengaruh Musik terhadap Mood dalam Belajar pada Mahasiswa Manajemen Dakwah UIN Suska Riau Tahun Ajaran 2019/2020.

\section{METODE PENELITIAN}

Penelitian yang dilakukan menggunakan metode survei dengan memberikan gambaran yang ada di lapangan, wawancara dan observasi untuk data pendukung. Penelitian dilakukan di UIN Suska Riau mahasiswa Manajemen Dakwah dengan populasi penelitian seluruh mahasiswa semester III Tahun Ajaran 2019/2020. Sampel yang digunakan dalam penelitian ini adalah 36 orang mahasiswa IIIA, IIIB, IIIC, IIID, IIIE dimana diambil tujuh orang dari masing-masing kelas.

Pengambilan data dilakukan dengan metode penyebaran angket. Angket disebarkan dengan menggunakan gformulir. Angket di isi oleh sebagian mahasiswa semester III Manajemen Dakwah yang menjadi sampel penelitian ini. Pertanyaan yang disebarkan berkenaan dengan pengaruh musik terhadap mood belajar mahasiswa. Angket diisi oleh sampel secara jujur. Penyebaran angket ini dimulai saat bulai Oktober 2019. Setelah itu peneliti melakukan wawancara lanjutan untuk mendapatkan data lebih dalam.

Teknik analisis data dalam penelitian ini menggunakan teknik deskriptif dengan mendeskripsikan data-data dan teori yang peneliti dapatkan.

\section{HASIL DAN PEMBAHASAN}

Berdasarkan angket yang disebar melalui google-formulir kepada 36 mahasiswa semester III pada tiga kategori (1) alasan mendengarkan musik saat belajar dan emnegrjakan tugas; (2) Jenis musik yang sering didengar; dan (3) dampak yang ditimbulkan saat mendengarkan musik : didapat bahwa $75 \%$ mahasiswa mendengarkan musik dalam belajar atau saat pengerjaan tugas kuliah dan $25 \%$ mahasiswa mendengarkan musik pada saat waktu kosong perkuliahan. $80 \%$ mahasiswa yang mendengarkan musik mempunyai alasan yang sama mengapa mereka mendengarkan musik ketika belajar, yaitu agar tidak bosan saat belajar, karena hobi mendengarkan musik dan meningkatkan kreativitas berfikir, menambah kosa kata. Sedangkan $13,3 \%$ mahasiswa yang mendengarkan musik beralasan mendengarkan musik saat belajar membuat mereka tenang. Dan sisanya beralasan mendengarkan musik saat belajar membuat pembelajaran yang sedang dipelajari mudah diingat, dapat menghilangkan rasa gugup dan suka penyanyinya. $80 \%$ mahasiswa yang mendengarkan musik saat belajar mendengarkan jenis musik yang berlirik (pop dan k-pop), berikut hasil wawancara lanjutan yang disampaikan subjek penelitian :

“..... jenis musik pop ini juga terkesan santai dan tidak terlalu bertempo cepat, sehingga nyaman didengarkan ketika belajar, fokus dan konsentrasi juga tidak hilang ketika mendengarkannya"

sedangkan $20 \% \quad$ lainnya mendengarkan musik yang tidak berlirik (instrumental). Berikut alasan mahasiswa lainnya :

“..... menurut mereka, mendengarkan jenis musik ini, karena mempengaruhi mood, musik yang lembut dan santai akan membantu dalam proses menemukan ide-ide baru saat mengerjakan tugas kuliah..."

Dampak mendengarkan musik bagi mahasiswa ada positif dan negatif, diantaranya $70 \%$ mahasiswa mengatakan dampak positif yang dirasakan saat 
mendengarkan musik baik dalam belajar dan mengerjakan tugas maupun saat waktu kosong dapat memunculkan ide-ide baru, membuat perasaan tenang, menghilangkan stres ketika belajar. Sedang 30\% lainnya merasakan ada juga dampak negatifnya seperti timbulnya rasa ketergantungan pada musik dan hilangnya prioritas utama mahasiswa yaitu belajar dengan konsentrasi penuh dalam menyelesaikan tugas perkuliahan.

Menurut (Gunawan, 2007)pengaruh yang dapat ditimbulkan oleh musik pada diri kita yaitu : (a) musik meningkatkan energi otot; (b) meningkatkan energi sel tubuh; (c) mempengaruhi detak jantung; (d) meningkatkan metabolisme tubuh; (e) mengurangi stres dan rasa sakit; (f) meningkatkan kecepatan penyembuhan dan pemulihan pasien operasi; (g) mengurangi rasa lelah dan mengantuk; (h) membantu meningkatkan kondisi emosi ke arah yang lebih baik; dan (i) merangsang kreativitas, kepekaan, dan kemampuan berpikir. Dengan pengaruh-pengaruh musik tersebut, dapat menghilangkan kebosanan mahasiswa saat belajar atau mengerjakan tugas. Terbukti dengan hasil penelitian bahwa tiga puluh dari tiga puluh enam mahasiswa MD semester III TA. 2019/2020 yang mendengarkan musik ketika belajar atau mengerjakan tugas beralasan musik dapat mengusir kebosanan. Sehingga anggapan negatif tentang belajar dan menyelesaikan tugas kuliah akan tergantikan dengan anggapan positif. Belajar bisa menjadi suatu kegiatan yang menyenangkan jika dibarengi dengan mendengarkan musik.

Orang mendengarkan musik untuk emngubah emosi, untuk melepaskan emosi, untuk mencocokkan emosi mereak saat ini, untuk menikmati atau menghibur diri dan untuk mengurangi stres ((Behne, 1997); (Juslin, P. N., \& Laukka, 2004); (Sloboda, J. A. \& O’Neill, 2001); (Zillman, D. \& Gan, 1997)). Dengan mendengarkan musik, kondisi emosi kita akan meningkat ke arah yang lebih baik.
Sehingga kita dapat menghilangkan bad mood dengan mendengarkan musik. Jika mood sedang tidak baik sehingga tidak ada semangat untuk belajar, mendengarkan musik sebelum belajar atau selama belajar akan menghilangkan bad mood, sehingga semangat untuk belajar akan muncul. Menurut (Konecni, 2003)penelitian musik dan emosi diawali oleh Hevner pada tahun 1936. (Hevner K, 1937) meminta subjek penelitian menuliskan sebuah kata sifat yang hadir dalam pikirannya saat musik dimainkan. Dari penelitian tersebut, Hevner (1936) berpendapat bahwa musik membawa sebuah arti emosi. Musk sanggup membuat pendengarnya sedih, bahagia, takut, gelisah, tenang, bahkan geli (Bernstein, M., \& Picker, 1972). Beberapa peneliti yakin bahwa musik dapat secara langsung menyebabkan munculnya emosi pada pendengar (Dibben, 2004; Gabrielsson, 2001-2002; Juslin dan Laukka, 2004; Juslin dan Sloboda, 2001)

Lalu jenis musik seperti apa yang baik digunakan untk membantu proses pembelajaran? dari hasil penelitian, Musik yang baik digunakan dalam proses belajar atau penyelesaian tugas adalah musik Pop dengan lirik. Musik Pop merupakan bentuk modern dari rock and roll. Terbentuk tahun 1950-an dan mulai diterima di Amerika Serikat, seniman yang memperkenalkan istilah Pop adalah Lawrence Alloway seorang pengamat seni rupa yang terinspirasi dari gerakan seni rupa di Amerika Serikat. Jenis musik ini menjadi Genre paling populer dan paling easy listening. Untuk membantu proses pembelajaran tidak harus selalu dengan musik Pop. Musik lain pun dapat digunakan untuk proses pembelajaran. Hanya saja, pada tahap awal lebih baik mendengarkan musik klasik (Gunawa, 2007).

\section{SIMPULAN}

Musik dinilai baik untuk membantu pemulihan mood dalam belajar, karena musik dapat mempengaruhi diri kita. 
Berikut merupakan pengaruh yang ditimbulkan musik pada diri kita : dengan musik menjadi tidak bosan saat belajar; meningkatkan kreativitas berfikir, menambah kosa kata; membuat relex dan tenang; pembelajaran yang sedang dipelajari mudah diingat; menghilangkan rasa gugup dan stres.

Musik yang biasanya didengarkan selama belajar atau penyelesaian tugas kuliah adalah musik berlirik seperti, Pop, K-Pop yang dapat digunakan untuk mendukung proses belajar mahasiswa. Alasan yang beragam dari kebiasaan mahasiswa dengan mendengarkan musik membuat suatu kebiasaan yang berdampak pada pola belajar mereka, baik damapk negatif maupun positif, tergantung bagaimana mereka mengontrol diri sendiri, namun kebanyakan dampak yang dirasakan ketika mendengarkan musik pada saat belajar adalah positif, karna musik dapat meransang proses berfikir otak dan mempengaruhi mood mereka dalam belajar.

Berdasarkan hasil pembahasan, penulis memberikan saran-saran kepada beberpa pihak, yaitu : (1) mahasiswa perlu mendengarkan musik tanpa lirik (instrumental) terlebih dahulu sebelum mendengarkan musik yang disukai (Pop) untuk menjaga stabilitas emosi dalam belajar; (2) untuk peneliti selanjutnya disarankan melakukan penelitian eksperimen untuk lebih mendapatkan pengaruh yang sangat signifikan dari musik dan mood tersebut, selain itu, tentukan sampel penelitian dengan menetapkan karakteristik yang lebih spesifik, sperti jenis kelamin, gaya belajar sampel penelitian.

\section{DAFTAR PUSTAKA}

Behne, K. E. (1997). The development of "Musikerleben" in adolescence: Howand why young people listen to music. In:Perception and cognition ofmusic. Psychology Press, ed. I.
Delie'ge \& J. A. Sloboda, 143-59.

Bernstein, M., \& Picker, M. (1972). An Introduction to Music (4th. Ed ., p. 1). NewJersey: Prentice Hall, Inc, Englewood Cliffs.

Goleman, D. (2003). Kecerdasan Emosi Untuk Mencapai Prestasi. Gramedia Pustaka Utama.

Gunawan, A. W. (2007). Genius Learning Strategy. Gramedia Pustaka Utama.

Hevner K. (1937). The affevtive value of of pitch and tempo in music.American. Journal of Psychology, 49, 621-630.

Juslin, P. N., \& Laukka, P. (2004). Expression, perception, and induction ofmusical emotions: A review and a questionnaire study of everyday listening. Journal of New MusicResearch, 33, 217-238.

Konecni, V. J. (2003). Review of P. N. Juslin and J. A. Sloboda (Eds.), 'Musicand Emotion: Theory and Research.'Music Perception. 'Music Perception, 0, 332-341.

Sloboda, J. A. \& O'Neill, S. A. (2001). Emotions in everyday listening to music.In: Music and emotion: Theory and research, ed. P. N. Juslin \& J. A.Sloboda. Oxford University Press.

Zillman, D. \& Gan, S. . (1997). No TitleMusical taste in adolescence. In:The socialpsychology of music, ed. D. J. Hargreaves \& A. C North. Oxford University Press. 